\title{
Effect of Different Combinations of Dietary Vitamin A, Protein Levels, and Monensin on Inflammatory Markers and Metabolites, Retinol-Binding Protein, and Retinoid Status in Periparturient Dairy Cows
}

\author{
Bruna C. Agustinho ${ }^{1}{ }^{(D)}$, Kirk C. Ramsey ${ }^{1}$, Chel Moore $^{2}$, Chia-Yu Tsai ${ }^{1}$, Cynthia M. Scholte ${ }^{1}$, Mark A. McGuire ${ }^{1}$ \\ and Pedram Rezamand ${ }^{1, *}$ \\ 1 Department of Animal, Veterinary, and Food Sciences, University of Idaho, Moscow, ID 83844, USA; \\ brunac@uidaho.edu (B.C.A.); kirkramseydvm@gmail.com (K.C.R.); tsai4799@vandals.uidaho.edu (C.-Y.T.); \\ cy.scholte@gmail.com (C.M.S.); mmcguire@uidaho.edu (M.A.M.) \\ 2 Elanco Animal Health, Greenfield, IN 46140, USA; chelmoore@nutriquest.com \\ * Correspondence: rezamand@uidaho.edu; Tel.: +1-(208)-885-5392
}

check for updates

Citation: Agustinho, B.C.; Ramsey, K.C. Moore, C.; Tsai, C.-Y.; Scholte, C.M.; McGuire, M.A.; Rezamand, P. Effect of Different Combinations of Dietary Vitamin A, Protein Levels, and Monensin on Inflammatory Markers and Metabolites, Retinol-Binding Protein, and Retinoid Status in Periparturient Dairy Cows. Animals 2021, 11, 2605. https://doi.org/ 10.3390/ani11092605

Academic Editors: Jimena Laporta and Amy Skibiel

Received: 27 July 2021

Accepted: 2 September 2021

Published: 5 September 2021

Publisher's Note: MDPI stays neutral with regard to jurisdictional claims in published maps and institutional affiliations.

Copyright: (c) 2021 by the authors. Licensee MDPI, Basel, Switzerland. This article is an open access article distributed under the terms and conditions of the Creative Commons Attribution (CC BY) license (https:// creativecommons.org/licenses/by/ $4.0 /)$.
Simple Summary: The transition period is a challenging time, which combines a massive increase in nutrient requirements and leads to a negative energy balance. Therefore, disorders related to negative energy balance, such as ketosis, are more frequent. In addition, in this period, oxidative stress increases, favoring immune suppression functions and inflammation, which may lead to increased susceptibility to other diseases such as metritis and mastitis. Therefore, the combination of ionophores, such as monensin, that mitigate the accentuated negative energy balance; vitamin A, which plays an important role in supporting the immune system; and a high level of crude protein might improve immune parameters in dairy cows in the transition period. This study demonstrated that monensin and vitamin A supplementation and high crude protein levels enhanced some vitamin status and inflammatory markers when used during the late prepartum period.

Abstract: The objective of this study was to determine the effect of feeding different combinations of dietary vitamin A supplementation ( 0 or $110 \mathrm{IU} / \mathrm{kg}$ body weight), protein $(10.3 \%$ or $12.2 \%)$, and an ionophore (monensin at 0 or $400 \mathrm{mg}$ /day) on retinoid metabolism and immune function of dairy cows. Eighty multiparous Holstein dairy cows were studied from $\mathrm{d}-35$ to +21 relative to expected parturition in a complete randomized block design with a $2 \times 2 \times 2$ factorial arrangement of treatments. The significance of treatments was declared at $p \leq 0.05$. Dairy cows receiving high crude protein $(\mathrm{CP})$ diets with monensin had a greater retinol-binding protein serum concentration than cows receiving high $\mathrm{CP}$ diets without monensin $(p=0.04)$. Animals supplemented with vitamin A showed lower SCC $(p=0.04)$ and a higher thiobarbituric acid reactive substances concentration $(p=0.06)$ than cows non-supplemented. Moreover, cows receiving low crude protein diets had a greater haptoglobin concentration $(p=0.01)$. In addition, cows fed a high crude protein diet had a greater TNF- $\alpha$ expression in peripheral blood mononuclear cells $(p=0.04)$. Animals fed diets without monensin had a greater serum haptoglobin on day 3 postpartum than those fed monensin $(p=0.01)$. Moreover, dietary vitamin A increased serum 13-cis retinoic acid postpartum. We conclude that vitamin A, crude protein levels, and monensin fed during the close-up period affect milk somatic cell count, some vitamin statuses, and inflammatory markers during early lactation.

Keywords: vitamin A; immune function; gene expression; mastitis; periparturient

\section{Introduction}

The transition period has been defined as approximately 3 weeks before to approximately 3 weeks after parturition [1]. Managing dairy cows during the transition period 
poses many challenges to the dairy industry. A primary challenge associated with the transition period is the massive increase in nutrient requirements through the end of gestation and initiating and maintaining lactation. It has been demonstrated that at 4 days postpartum, a healthy cow's intake of net energy and metabolizable protein only accounts for $65 \%$ and $75 \%$, respectively, of her total requirements [2]. In addition, during the transition period, intake is reduced because of the hormonal changes [3]. Therefore, an increase in nutrient requirements is typically not met by nutrient intake. The accentuated negative energy balance favors the occurrence of several metabolic disorders and diseases, such as ketosis and displacement of the abomasum [4,5].

Monensin is an ionophore that has been used in transition dairy cows to mitigate the consequences of the negative energy balance [6]. Monensin modulates the rumen microbiome, leading to more propionate production [7] and providing more energy to the animal because propionate increases hepatic gluconeogenesis [7]. In addition, monensin reduces the ketone body [8,9] in blood circulation, indicating a reduction in lipolysis. Moreover, monensin has been related to improvement in the immune system [10].

Furthermore, during the transition period, oxidative stress is increased, leading to immune suppression functions and inflammation, which may set the stage for other diseases such as metritis and mastitis [11]. Therefore, some vitamins, such as vitamin A, play an important role in supporting the immune system [12]. Vitamin A and its derivatives have been researched to understand their role in this critical period. Retinol, the most abundant form of vitamin A, is essential for growth, vision, immunity, and epithelial cell differentiation and proliferation $[13,14]$. However, it has been shown that during the transition period, plasma retinol concentrations decrease dramatically and do not regain until about 4 weeks postpartum [15]. In addition, the literature reported that retinol-binding protein (RBP) concentration in the serum of dairy cows might be modulated by the dietary crude protein concentration [16]. Blood vitamin A concentration has been associated with the udder health of dairy cows, more specifically, the severity of mastitis $[17,18]$. Additionally, retinol is related to the proliferation and apoptosis of cells in the mammary epithelial $[19,20]$ and might affect the milk yield.

The meta-analysis by Husnain and Santos [21] showed that greater protein levels in prepartum diets could also increase pre- and postpartum intake and more milk, milk fat, and milk protein in primiparous cows. However, there is no evidence in the literature about a diet that combines the effects of a greater protein, vitamin $\mathrm{A}$ as a booster to the immune system, and monensin as an energy metabolism modulator. We hypothesized that vitamin A supplementation combined with a high protein level and monensin inclusion in the peripartum would provide a better nutrient input, increase retinol-binding protein leading to a greater retinol level, thus better health status of the mammary glands, as well as raising the delivery of retinol into the milk. Therefore, our objectives were to determine the effect of feeding a combination of dietary vitamin A, protein levels, and an ionophore on retinoid metabolism and the immune function of periparturient dairy cows.

\section{Materials and Methods}

\subsection{Animals and Experimental Diets}

All the animal procedures were approved by the Institutional Animal Care and Use Committee of the University of Idaho (IACUC protocol number 2014-78).

Ninety-four multiparous cows started the experiment from day -35 relative to the expected calving date to day 21 postpartum; however, 14 animals from different treatments were removed because of clinical hypocalcemia $(n=5)$, foot issues/lameness $(n=4)$, mastitis $(n=3)$, and extreme calving difficulty $(n=2)$. There was no relationship between the treatments and the incidence of health issues or calving difficulty because the affected dairy cows belonged randomly to different treatments (protein level: high, $n=7$ vs. low, $n=7$; vitamin A: no, $n=4$ vs. yes, $n=10$; monensin: no, $n=4$ vs. yes, $n=10$ ). Eighty multiparous Holstein cows that completed the experiment were included in the final analyses. Cows were assigned to a treatment group in a $2 \times 2 \times 2$ factorial arrangement of treatments 
in a completely randomized block design. The factors consisted of dietary protein levels $(10.3 \%$ or $12.2 \%)$, vitamin A levels ( 0 or $110 \mathrm{IU} / \mathrm{kg}$ body weight), and monensin levels ( 0 or $400 \mathrm{mg} /$ day). The animals were fed twice daily, one of eight dry cow ration combinations from $-35 \mathrm{~d}$ relative to the expected calving date (Table 1). The control treatment preparturition was designated as low protein, no monensin, no vitamin A. After parturition, all animals were fed with the same lactation diet, formulated according to NRC (2001) [22]. The postpartum diets consisted of $1.47 \mathrm{Mcal} /$ day, $16.8 \%$ crude protein, no monensin, and 72,000 IU/head per day of vitamin A in the form of a liquid supplement.

Table 1. Ingredient and chemical composition of the experimental diets.

\begin{tabular}{|c|c|c|c|}
\hline \multirow{2}{*}{ Item } & \multicolumn{3}{|c|}{ Ration } \\
\hline & Prepartum (HP) & Prepartum (LP) & Postpartum \\
\hline \multicolumn{4}{|l|}{ Ingredients $(\%$ of $\mathrm{DM})$} \\
\hline Alfalfa hay & 18.11 & 18.06 & 15.9 \\
\hline Grass hay & 23.50 & 22.06 & 5.0 \\
\hline Wheat straw & 11.01 & 10.15 & - \\
\hline Soybean, hulls & 12.8 & 12.8 & - \\
\hline Soybean, meal & 14.3 & - & - \\
\hline Rolled barley & 4.68 & 9.42 & 17.0 \\
\hline Dry distiller corn grain with solubles & 7.96 & 11.03 & 12.82 \\
\hline Corn, dry & 3.12 & 11.84 & 15.32 \\
\hline Sodium bicarbonate & - & - & 0.41 \\
\hline Liquid mineral/vitamin pre-mix ${ }^{1}$ & 4.53 & 4.64 & 4.50 \\
\hline Calcium soaps of fatty acids ${ }^{2}$ & - & & 1.35 \\
\hline Triticale silage $^{3}$ & - & - & 13.01 \\
\hline Canola meal & - & - & 14.99 \\
\hline \multicolumn{4}{|l|}{ Chemical analysis (\% of DM) } \\
\hline $\mathrm{DM}$ & 59.10 & 57.28 & 63.83 \\
\hline $\mathrm{CP}$ & 12.2 & 10.3 & 16.8 \\
\hline NDF & 49.4 & 46.9 & 40.8 \\
\hline ADF & 32.9 & 31.0 & 26.7 \\
\hline Ether extract & 1.40 & 1.46 & 3.22 \\
\hline NFC & 28.03 & 32.42 & 30.03 \\
\hline $\mathrm{Ca}$ & 0.7 & 0.7 & 0.7 \\
\hline $\mathrm{P}$ & 0.3 & 0.3 & 0.5 \\
\hline $\mathrm{Mg}$ & 0.2 & 0.2 & 0.2 \\
\hline $\mathrm{K}$ & 1.92 & 1.74 & 1.48 \\
\hline $\mathrm{NE}_{\mathrm{L}}, \mathrm{Mcal} / \mathrm{kg}$ of $\mathrm{DM}$ & 1.34 & 1.38 & 1.47 \\
\hline
\end{tabular}

${ }^{1}$ Performix, Caldwell, ID. Vitamin A excluded in prepartum; ${ }^{2}$ EnerGII; Virtus Nutrition, Corcoran, CA; ${ }^{3}$ Triticale silage: $37 \%$ of $\mathrm{DM}$ (as fed). $\mathrm{DM}=$ dry matter; $\mathrm{CP}=$ crude protein; $\mathrm{NDF}=$ neutral fiber detergent; $\mathrm{ADF}=$ acid fiber detergent; NFC $=$ non-fibrous carbohydrates.

Liver biopsy samples were taken between ribs 12 and 13 on days $-35,-3,+3,+10$, and +21 relative to parturition. Tissue samples were immediately frozen in liquid nitrogen and stored at $-80{ }^{\circ} \mathrm{C}$ until processing. Blood samples were collected on days $-35,-21$, $-14,-7,+1,+2,+3,+6,+9,+12,+15,+18$, and +21 by coccygeal venipuncture using $10 \mathrm{~mL}$ blood vacutainer tubes (BD Diagnostics, Franklin Lakes, NJ, USA). Blood samples were centrifuged at $1500 \times \mathrm{g}$ for $15 \mathrm{~min}$ at $4{ }^{\circ} \mathrm{C}$, and the serum was stored at $-80{ }^{\circ} \mathrm{C}$ until metabolites were analyzed. Additional blood samples were collected using vacutainer tubes and used to obtain Peripheral Blood Mononuclear Cells (PBMC). Composite milk samples were obtained at the first, second, and third milking postpartum and every 3 days thereafter. Milk samples were analyzed for somatic cell count (SCC; Washington DHIA, Burlington, WA, USA) and vitamin concentration.

\subsection{Serum Vitamin Analyses}

All vitamin analyses were conducted by reversed-phase HPLC (Waters e2695 Separation Module, Waters Corp., Milford, MA, USA) with a photodiode array detector (Waters 
2998, Waters Corp., Milford, MA, USA), as described by Tsai et al. [23]. To determine serum 13-cis retinoic acid and all-trans retinoic acid concentrations, $400 \mu \mathrm{L}$ serum samples were mixed with $420 \mu \mathrm{L}$ of acetonitrile and $20 \mu \mathrm{L}$ of acetic acid. One aliquot of $20 \mu \mathrm{L}$ of retinol acetate (Sigma-Aldrich, St. Louis, MO, USA) was used as the internal standard. Samples were extracted twice with $1.5 \mathrm{~mL}$ of a mixture of 6.5:1.5 hexane: isopropanol and $0.2 \mathrm{~mL}$ of HPLC-grade water, and the hexane layer was removed via evaporation under a light flow of nitrogen gas. The residue was re-suspended in 200 $\mu \mathrm{L}$ of a 50:50 mixture of the mobile phase solutions, and $100 \mu \mathrm{L}$ was injected into the instrument. Separation of retinoids was performed using an isocratic gradient on a Waters C18 CSH $3.5 \mu \mathrm{m}$ column (4.6 mm $\times 75 \mathrm{~mm}$, Waters Corp.). The mobile phase consisted of two solvents. Solvent A consisted of a $10 \mathrm{mM}$ ammonium acetate solution in HPLC grade water, and Solvent B consisted of acetonitrile, isopropyl alcohol, and tetrahydrofuran (45:45:10) at a flow rate of $1 \mathrm{~mL} / \mathrm{min}$.

Serum retinol, $\alpha$-tocopherol, and $\beta$-carotene concentrations were determined similar to serum 13-cis retinoic acid and all-trans retinoic acid except retinol palmitate used as the internal standard, and samples were analyzed using a non-isocratic method. A single mobile phase consisting of acetonitrile, dichloromethane, methanol, and n-butanol (72:12:8:0.08) and a $1.25 \mathrm{~mL} / \mathrm{min}$ flow rate was used.

Milk retinol, $\alpha$-tocopherol, and $\beta$-carotene were determined in a similar procedure used to serum, except for the extraction. Milk samples were processed by mixing $2.5 \mathrm{~mL}$ of milk with $5 \mathrm{~mL}$ of $1 \%$ pyrogallic acid solution dissolved in 200 proof HPLC grade ethanol, then mixed with $10 \mathrm{~mL}$ of a $50 \%$ potassium hydroxide solution. Samples were placed in a water bath for $7 \mathrm{~min}$ at $70{ }^{\circ} \mathrm{C}$, cooled down, posteriorly, $10 \mathrm{~mL}$ of HPLC grade Petroleum Ether was added, and samples were mechanically shaken at high speed for $10 \mathrm{~min}$. Specifically, $15 \mathrm{~mL}$ of HPLC grade water were added to each sample, and the samples were centrifuged for $10 \mathrm{~min}$. Once complete, $5 \mathrm{~mL}$ of the upper layer was extracted and evaporated under a light nitrogen gas flow. Samples were dissolved in $100 \mu \mathrm{L}$ of HPLC grade methanol, $400 \mu \mathrm{L}$ of starting mobile phase (as described in serum analysis), and $100 \mu \mathrm{L}$ was injected into the instrument.

\subsection{Serum Metabolites}

Serum haptoglobin concentration was determined using an enzymatic assay (Tridelta, Maynooth, Co., Kildare, Ireland). A total of $50 \mu \mathrm{L}$ of the first reagent (stabilized hemoglobin) was added to $3.25 \mu \mathrm{L}$ of serum, followed by $70 \mu \mathrm{L}$ of the second reagent (chromogen). Samples were incubated for $5 \mathrm{~min}$ at room temperature, and the absorbance was determined in a spectrophotometer (Synergy 2 microplate spectrophotometer, BioTek, Winooski, VT, USA) at $600 \mathrm{~nm}$. Concentrations were determined using a standard linear curve according to instructions provided by the manufacture. Serum RBP concentration was determined using a commercially available ELISA kit (BioSource, San Diego, CA, USA) according to instructions provided by the manufacturer. Briefly, $100 \mu \mathrm{L}$ of sample was added to a pre-coated 96-well plate, and $50 \mu \mathrm{L}$ of the conjugate (RBP4-HRP) was added to each well. The plate was incubated for $1 \mathrm{~h}$ at $37^{\circ} \mathrm{C}$. Upon completion of the incubation, each well was washed 5 times using a $1 \times$ wash solution. Posteriorly, $50 \mu \mathrm{L}$ of solution A (substrate for HRP enzyme) and B (stop reagent) were added to each well, and the plate was covered and incubated for $15 \mathrm{~min}$ at $37^{\circ} \mathrm{C}$. After incubation, $50 \mu \mathrm{L}$ of stop solution was added, and the absorbance was determined in a spectrophotometer (Synergy 2 microplate spectrophotometer, BioTek, Winooski, VT, USA) at $450 \mathrm{~nm}$. The standard curve fit an exponential model using SAS, and concentration was determined for each sample. Serum concentration of malondialdehyde (MDA) was determined via colorimetric assay testing for thiobarbituric acid reactive species (TBARS; Caymen Chemical Company, Ann Arbor, MI, USA) according to the manufacturer's instruction. A total of $50 \mu \mathrm{L}$ of serum was mixed with $50 \mu \mathrm{L}$ of sodium dodecyl sulfate (SDS) solution, and $2 \mathrm{~mL}$ of color reagent (thiobarbituric acid, acetic acid, and sodium hydroxide) were added to each sample. Samples were boiled for $1 \mathrm{~h}$ and immediately cooled on ice for $10 \mathrm{~min}$. Samples were centrifuged, transferred on a 
96 well plate, and absorbance determined in a spectrophotometer (Synergy 2 microplate spectrophotometer, BioTek, Winooski, VT, USA) at $532 \mathrm{~nm}$. A standard linear curve was created, and MDA concentration was determined according to the standard curve. The intraand inter-assays' coefficients of variation were determined to serum metabolites and RBP, and when those coefficients were higher than $10 \%$, the samples were re-analyzed.

\subsection{Peripheral Blood Mononuclear Cells (PBMC) Isolation}

Peripheral blood mononuclear cells (PBMC) were isolated, according to Scholte et al., [24] with modifications, from $50 \mathrm{~mL}$ of blood by gradient centrifugation using a mixture of Histopaque 1077 and 1119 (Sigma Aldrich, St. Louis, MO, USA). After centrifugation at $456 \times g$ for $1 \mathrm{~h}$ at room temperature, plasma was discarded, and the buffy coat and red blood cells were collected. Red blood cells were lysed using a $10 \% \mathrm{NaCl}$ solution and water, then further washed with phosphate-buffered saline (PBS). Samples were separated, and $\mathrm{PBMC}$ was stored at $-80^{\circ} \mathrm{C}$ for further processing for gene expression.

\subsection{Gene Expression Analysis}

Total RNA was extracted from PBMC and liver using NucleoSpin ${ }^{\circledR}$ RNA (Macherey Nagel, Düren, Germany), as described by the manufacturer. The RNA concentration was determined using NanoDrop ND-1000 (NanoDrop Technologies, Rockland, DE, USA) spectrophotometer. The complementary DNA (cDNA) synthesis was carried out using Applied Biosystems High-Capacity Reverse Transcription Kit (Applied Biosystems, Foster City, CA, USA), as described by the manufacturer.

Real-time reverse-transcribed PCR was carried out in a 7500 Fast real-time PCR system (Applied Biosystems, Foster City, CA, USA) using custom-designed TaqMan MGB probes on targeted genes Interleukin-1beta (IL-1 $\beta$ ), Interleukin-6 (IL-6), Tumor Necrosis Factoralpha (TNF- $\alpha$ ), and Intercellular Adhesion Molecule (ICAM) in PBMC. The bovine RPS9 and GAPDH were used as endogenous controls, also called housekeeping genes (Table 2). Reaction mixture included $2 \mu \mathrm{L}$ of cDNA, $10 \mu \mathrm{L}$ of TaqMan ${ }^{\circledR}$ Universal Master Mix II with Uracil-N-Glycosylase (Applied Biosystems, Foster City, CA, USA), $1 \mu \mathrm{L}$ of Applied Biosystems 20X custom primer probe mixture (Applied Biosystems, Foster City, CA, USA), and $7 \mu \mathrm{L}$ of RNase-free water.

Table 2. Custom bovine primer/probe sets used for reverse transcription-PCR.

\begin{tabular}{|c|c|c|c|c|}
\hline \multirow{2}{*}{$\begin{array}{c}\text { Symbol } \\
\text { IL-1 } \beta\end{array}$} & \multirow{2}{*}{$\begin{array}{c}\text { Amplicon Length (bp) } \\
69\end{array}$} & \multirow{2}{*}{$\begin{array}{c}\text { Accession No. } \\
\text { NM_174093 }\end{array}$} & \multicolumn{2}{|c|}{ Primer (F, Forward; R, Reverse) and Probe } \\
\hline & & & F & GCTCTCСАССТССТСТСАСА \\
\hline & & & $\mathrm{R}$ & СТСТССТTGСACAAAGСТCATG \\
\hline & & & Probe & CAGAACACCACTTCTCG \\
\hline \multirow[t]{3}{*}{ IL-6 } & 65 & NM_001015617 & $\mathrm{F}$ & GGACGGATGCTTCCAATCTG \\
\hline & & & $\mathrm{R}$ & GAAGACCAGCAGTGGTTCTGAT \\
\hline & & & Probe & CAATCAGGCGATTTGC \\
\hline \multirow[t]{3}{*}{ TNF- $\alpha$} & 82 & NM_173966 & $\mathrm{F}$ & GCTCTCTTGGCAGCTTTCCT \\
\hline & & & $\mathrm{R}$ & GGCATCGAAGTTCTGTACTCATTCT \\
\hline & & & Probe & CAGAACTGCAGCTTCAC \\
\hline \multirow[t]{3}{*}{ ICAM } & 73 & NM_174348 & $\mathrm{F}$ & GCAGGTGGTCCACAAACAC \\
\hline & & & $\mathrm{R}$ & GCAATCCCGCTGGTCTAGTC \\
\hline & & & Probe & ATGTCCTGTACGGCCCC \\
\hline \multirow[t]{3}{*}{ RPS9 } & 71 & XM_864261 & $\mathrm{F}$ & GGCGGCTCGTCCGTATC \\
\hline & & & $\mathrm{R}$ & AATCTTCAGGCCCAGGATGTAATC \\
\hline & & & Probe & СССТСATCCAGCACCC \\
\hline \multirow{3}{*}{ GPDH } & 68 & NM_001034034 & $\mathrm{F}$ & GCTACACTGAGGACCAGGTT \\
\hline & & & $\mathrm{R}$ & AGCATCGAAGGTAGAAGAGTGAGT \\
\hline & & & Probe & CTCCTGCGACTTCAAC \\
\hline
\end{tabular}

IL-1 $\beta$ = Interleukin-1 beta; IL-6 = Interleukin-6; TNF- $\alpha$ = Tumor Necrosis Factor-alpha; ICAM = Intercellular Adhesion Molecule; RPS9 = Ribosomal protein subunit-9; GPDH = Gliceraldeído-3-fosfato desidrogenase. 


\subsection{Statistical Analyses}

The experimental design was a $2 \times 2 \times 2$ factorial arrangement of treatments in a completely randomized block design. Pre-planned orthogonal contrasts were used to compare individual dietary main effects (protein, vitamin A, and monensin), as well as twoway interaction between the main factors on the response variables measured. Secondarily, variables were compared over time. Response variables were analyzed with repeatedmeasures ANOVA using the MIXED model procedure (Version 9.3, SAS Institute Inc., Cary, NC, USA). Sources of variation in the model included effects of main factors and 2-way interactions amongst the main effects. When analyzed over time, time was also included in the model. Significance was declared at $p \leq 0.05$ with trends toward significance when $p<0.1$. Separation of means was accomplished using the diff option within SAS to perform a pair-wise test between means. Intercept was designated as the random effect, with the subject being the cow. Several covariate structures, including compound symmetry, unstructured, autoregressive(1), variance components, and Toeplitz matrix, were tested; however, compound symmetry fit the model best, likely because sampling periods were not equidistant. Samples taken on periods previously listed in the sampling section were used for the analysis of treatment and time. Data are presented as least square means (LSM) \pm standard errors of the mean (SEM).

Gene expression data were analyzed using delta $\mathrm{Ct}$ values (Ct values normalized to the average of the endogenous control genes, GAPDH and RPS9) and are graphically presented as fold change (2- $\Delta \Delta \mathrm{Ct})$ relative to the control treatment (low protein, no supplemental vitamin $\mathrm{A}$, no monensin).

\section{Results and Discussion}

\subsection{Milk Somatic Cell}

Milk somatic cell count and linear somatic cell score were affected by dietary treatments (Table 3). Milk somatic cell count was lower for cows that received vitamin A supplementation prepartum compared with those that did not receive vitamin A when the first, second, and third milkings were included in the analysis $(p=0.04$, Figure 1$)$. When the first three milkings were removed, there was a monensin $\times$ vitamin A interaction $(p=0.05)$; cows supplemented with vitamin A and monensin had the lowest SCC. The low SCC is possibly attributed to a combination of a balanced immune response (from vitamin A supplementation) combined with improved energy metabolism because of monensin.

Table 3. Milk somatic cell count and linear somatic cell score during the first 21 days of lactation for multiparous Holstein dairy cows $(n=80$, total) that were fed diets with crude protein levels $(10.3 \%, n=40$ vs. $12.2 \%$ dry matter basis, $n=40)$, and within each crude protein group fed monensin (400 mg/day per head or none) and vitamin A (110 IU/ kg body weight or none) during prepartum period (from day -35 to the day of calving). All cows received a common lactation ration postpartum.

\begin{tabular}{|c|c|c|c|c|c|c|c|c|c|c|c|c|c|}
\hline \multirow[b]{3}{*}{ Items } & \multicolumn{6}{|c|}{ Main Effect } & \multirow{3}{*}{ SEM $^{1}$} & \multirow{2}{*}{\multicolumn{6}{|c|}{$p$-Value }} \\
\hline & \multicolumn{2}{|c|}{ Vitamin A } & \multicolumn{2}{|c|}{ Protein } & \multicolumn{2}{|c|}{ Monensin } & & & & & & & \\
\hline & $(+)$ & $(-)$ & High & Low & $(+)$ & $(-)$ & & Pro & Mon & Vit. A & $\begin{array}{c}\text { Pro } \times \\
\text { Vit. }\end{array}$ & $\begin{array}{l}\text { Mon } \\
\times \text { Vit. }\end{array}$ & $\begin{array}{c}\text { Pro } \times \\
\text { Mon }\end{array}$ \\
\hline $\mathrm{SCC}^{2}$ & 706.9 & 1246 & 1003 & 949.5 & 1026 & 927.5 & 198.1 & 0.84 & 0.71 & 0.04 & 0.99 & 0.35 & 0.48 \\
\hline SCLs $^{3}$ & 2.77 & 3.09 & 2.94 & 2.91 & 2.99 & 2.86 & 0.15 & 0.86 & 0.52 & 0.11 & 0.99 & 0.34 & 0.50 \\
\hline$* \mathrm{SCC}^{2}$ & 441.2 & 1008 & 786.4 & 663.6 & 637.8 & 812.1 & 129.2 & 0.47 & 0.31 & $<0.01$ & 0.82 & 0.05 & 0.17 \\
\hline$* \mathrm{SCLs}^{3}$ & 2.40 & 2.73 & 2.62 & 2.51 & 2.59 & 2.54 & 0.15 & 0.56 & 0.82 & 0.10 & 0.79 & 0.22 & 0.21 \\
\hline
\end{tabular}

${ }^{1}$ Largest SEM reported; ${ }^{2}$ SCC: somatic cell count $(\times 1000 / \mathrm{mL}) ;{ }^{3}$ SCLs: somatic cell linear score; ${ }^{*}$ first, second, and third milk samples not included in analysis. Pro = dietary crude protein; Mon $=$ monensin; Vit. A = dietary vitamin A; Pro $\times$ Vit. = dietary crude protein and vitamin A interaction; Mon $\times$ Vit. $=$ monensin and dietary vitamin A interaction; Pro $\times$ Mon $=$ dietary crude protein and monensin interaction. 


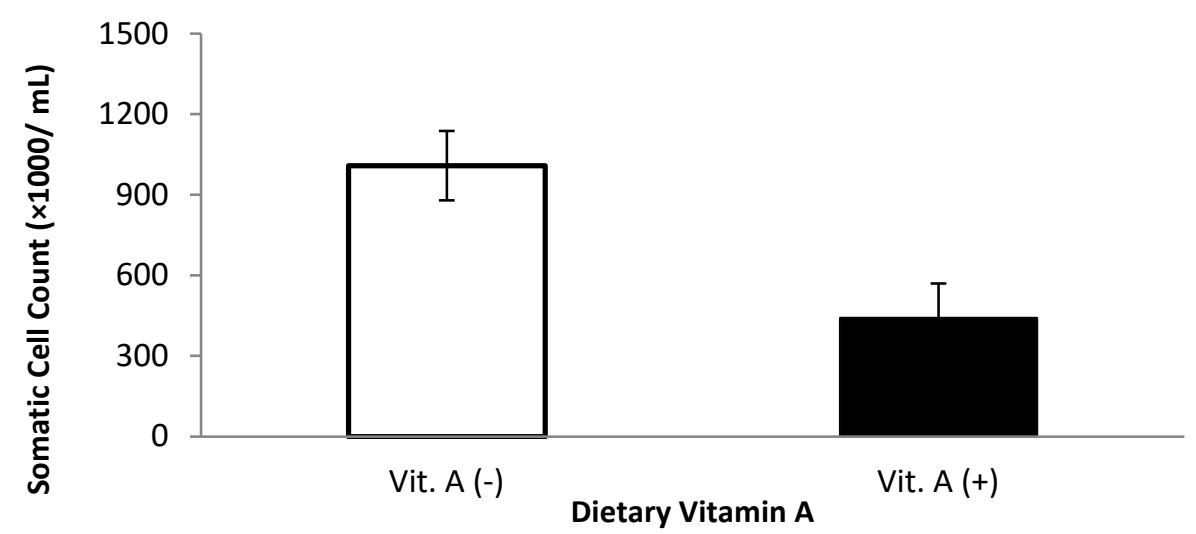

Figure 1. Somatic cell count for multiparous Holstein dairy cows $(n=80$, total) that were fed diets with crude protein levels $(10.3 \%, n=40$ vs. $12.2 \%$ dry matter basis, $n=40)$, and within each crude protein group that was fed monensin ( $400 \mathrm{mg}$ /day per head or none) and vitamin A (110 IU/ kg body weight or none) during prepartum period (from day -35 to the day of calving). All cows received a common lactation ration postpartum. Dietary vitamin A interaction $(p=0.04)$.

Monensin and other ionophores have been related to reduced incidence of intramammary infection $[25,26]$ in dairy cows, and this is likely related to an improvement in the immune function because of better energy metabolism [27]. Heuer et al. [25] noticed that cows in the first lactation were less predisposed to develop intramammary infections when treated with monensin before calving. This lower incidence in the literature is attributed to the better utilization of endogenous energy sources, leading to a better immune response and increased energy metabolites related to immunosuppression [28]. On the other hand, rats with inoculation of LPS in the mammary gland showed a greater migration of PMN to the tissue; however, when the treatment was combined with vitamin A supplementation, the effect of LPS was ameliorated [29]. Therefore, vitamin A has been related to the immune response in the mammary glands. This understanding may explain the monensin $\times$ vitamin A interaction and why cows not receiving vitamin A supplements had greater SCC overall. However, the results for SCC content contradict with observed by Oldham et al. [30] and Puvogel et al. [31], where SCC was not affected in dairy cows supplemented with vitamin A at 50,000 and 550,000 IU/day, respectively. Additionally, when $\beta$-carotene-a precursor of vitamin A-instead of vitamin A was supplemented in dairy cows at the prepartum, the SCC was not affected [32].

Similar results have also been observed using the rat model. S. aureus is the most common bacterium that causes mastitis [33], and Wiedermann et al. [34] observed that vitamin A deficiency predisposes rats to S. aureus infection. Wiedermann et al. [34] also indicated decreased phagocytic activity and bacterial killing of peritoneal macrophage for S. aureus. One of the main reasons neutrophil function might be diminished during vitamin A deficiency is that neutrophils and other granulocytes, developed from myeloid stem cells in the bone marrow, are mediated by retinoic-acid-binding to retinoic acid receptors to stimulate gene expression [35]. In general, SCC and SC linear score declined over the $21 \mathrm{~d}$ postpartum (data not shown), possibly related to the higher SCC at the beginning for the lactation.

\subsection{Milk Vitamins}

Milk samples were tested over five time points (day 1 , day 3 , day 9 , day 15 , and day 21) during early lactation, and there was a reduction in milk vitamin A ( $p<0.01$; data not shown) and $\beta$-carotene ( $p<0.01$; data not shown) concentrations over time in postpartum. These reductions corroborate Johnston et al. [36] for milk vitamin A and $\beta$ carotene concentrations early postpartum. As reported in the literature, colostrum presents a greater concentration of vitamin A and E than milk [37]; therefore, the reduction observed in those vitamins early postpartum is possibly attributed to the transition from colostrum 
to milk. Furthermore, there was a protein $\times$ monensin interaction $(p=0.01$, Table 4$)$ for retinol concentration, where cows receiving low protein and no monensin had the lowest milk retinol concentration compared with all other treatment groups.

Table 4. Milk vitamin concentrations $(\mu \mathrm{g} / \mathrm{mL})$ during the first 21 days of lactation for multiparous Holstein dairy cows ( $n=80$, total) that were fed diets with crude protein levels $(10.3 \%, n=40 \mathrm{vs.} 12.2 \%$ dry matter basis, $n=40)$, and within each crude protein group that was fed monensin ( $400 \mathrm{mg} /$ day per head or none) and vitamin A (110 IU $/ \mathrm{kg}$ body weight or none) during prepartum period (from day -35 to the day of calving). All cows received a common lactation ration postpartum.

\begin{tabular}{|c|c|c|c|c|c|c|c|c|c|c|c|c|c|}
\hline & \multicolumn{6}{|c|}{ Main Effect } & \multirow{3}{*}{ SEM $^{1}$} & \multirow{2}{*}{\multicolumn{6}{|c|}{$p$-Value }} \\
\hline & \multicolumn{2}{|c|}{ Vitamin A } & \multicolumn{2}{|c|}{ Protein } & \multicolumn{2}{|c|}{ Monensin } & & & & & & & \\
\hline & $(+)$ & $(-)$ & High & Low & $(+)$ & $(-)$ & & Pro & Mon & Vit. A & $\begin{array}{l}\text { Pro } \times \\
\text { Vit. A }\end{array}$ & $\begin{array}{c}\text { Mon } \\
\times \text { Vit. } \\
\text { A }\end{array}$ & $\begin{array}{r}\text { Pro } \times \\
\text { Mon }\end{array}$ \\
\hline Retinol & 2.23 & 1.96 & 2.23 & 1.96 & 2.16 & 2.03 & 0.12 & 0.07 & 0.45 & 0.09 & 0.68 & 0.35 & 0.01 \\
\hline$\alpha-\mathrm{TOC}$ & 0.40 & 0.45 & 0.43 & 0.43 & 0.42 & 0.44 & 0.02 & 0.99 & 0.47 & 0.10 & 0.51 & 0.20 & 0.04 \\
\hline$\beta-\mathrm{CAR}$ & 1.03 & 1.03 & 1.14 & 0.93 & 0.98 & 1.08 & 0.11 & 0.13 & 0.46 & 0.97 & 0.81 & 0.80 & 0.23 \\
\hline
\end{tabular}

${ }^{1}$ Largest SEM reported; $\alpha$-TOC $=\alpha$-tocopherol; $\beta$-CAR = $\beta$-carotene; Pro = dietary crude protein; Mon = monensin; Vit. A = dietary vitamin A; Pro $\times$ Vit. $=$ dietary crude protein and vitamin A interaction; Mon $\times$ Vit. $=$ monensin and dietary vitamin $\mathrm{A}$ interaction; Pro $\times$ Mon $=$ dietary crude protein and monensin interaction.

Milk retinol was affected by dietary crude protein over time (Figure 2), where cows receiving high crude protein had greater $(p=0.04)$ milk retinol than cows receiving low crude protein 1 day after calving. Minimal research has been performed investigating the relationship between milk retinol and prepartum dietary crude protein. Lindberg et al. [16] reported a significant difference in serum RBP concentration between cows receiving low and high crude protein diets during the prepartum period and speculated that the effect of dietary protein levels on RBP might be related to the amino acid availability to synthesize RBP. This might explain the greater milk retinol concentration at day 1 postpartum from cows receiving high CP diets. Although, more investigations are required to better understand the potential effect of protein $\times$ monensin interaction on the milk retinol concentration.

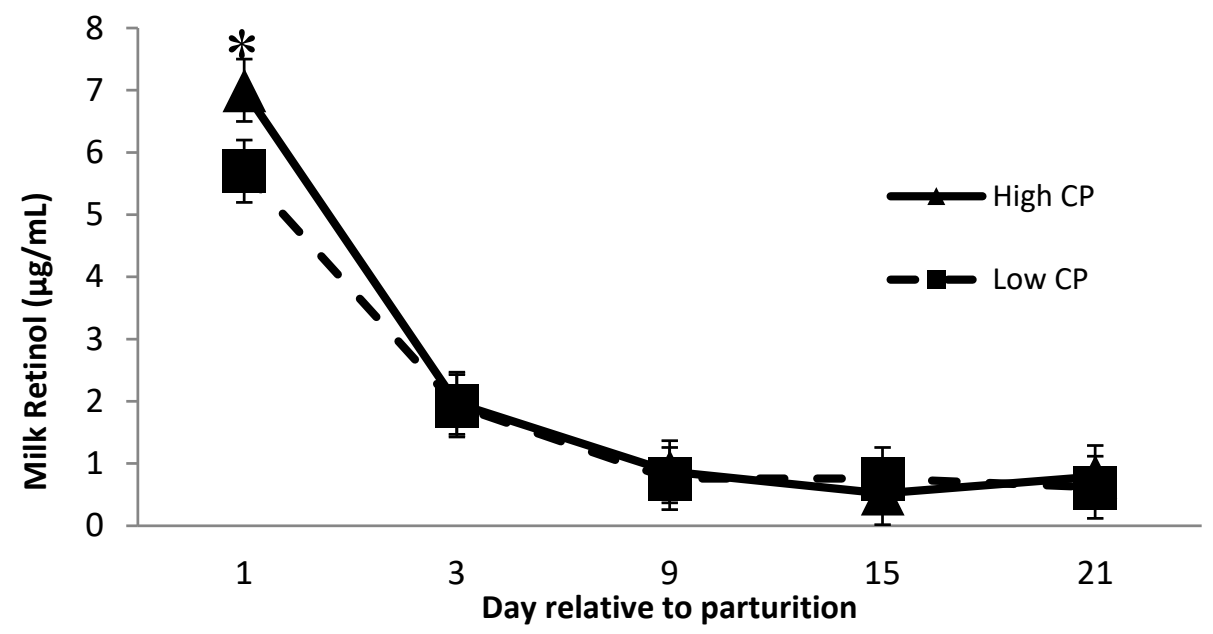

Figure 2. Milk retinol concentration the first 21 days of lactation for multiparous Holstein dairy cows ( $n=80$, total) that were fed diets with crude protein levels $(10.3 \%, n=40$ vs. $12.2 \%$ dry matter basis, $n=40$ ) and within each crude protein group that was fed monensin (400 $\mathrm{mg} /$ day per head or none) and vitamin A (110 IU / $\mathrm{kg}$ body weight or none) during prepartum period (from day -35 to the day of calving). All cows received a common lactation ration postpartum. Dietary crude protein $\times$ time interaction $(p=0.04)$. Asterisks show significant difference at time point specified. 
Milk $\alpha$-tocopherol concentration was not affected by dietary treatments when observed over time ( $p=0.80$, data no shown). However, an interaction $(p=0.04)$ between dietary protein and monensin on milk $\alpha$-tocopherol concentration was observed (Table 4). The animals fed diets with high crude protein combined with monensin showed a lower $\alpha$-tocopherol concentration in milk than animals supplemented with high $\mathrm{CP}$ but no monensin $(0.392$ vs. $0.465 \mathrm{ug} / \mathrm{mL})$. There is no evidence in the literature about the effect of high crude protein diets and monensin inclusion on milk $\alpha$-tocopherol concentration; therefore, further investigation is required to better understand the potential impact. The $\beta$ carotene concentration in the milk was not affected among the treatments $(p>0.13)$. Milk $\alpha$-tocopherol and $\beta$-carotene followed an expected curve over time, similar to what was observed with milk retinol concentrations.

\subsection{Serum Metabolites and Retinol-Binding Protein}

Serum haptoglobin is an acute-phase protein that has been used as an inflammatory marker in dairy cows [38-40]. Haptoglobin acts by sequestering iron found in hemoglobin and avoiding the utilization of iron by bacteria. Furthermore, free hemoglobin promotes oxidation, so haptoglobin is also affected indirectly as an antioxidant [41]. Our observations follow similar observations in serum haptoglobin during the transition period, where serum haptoglobin concentrations increase near the time of parturition $[40,42]$. There was a monensin $\times$ time interaction ( $p=0.01$, Figure 3 ) on serum haptoglobin concentration. Cows that did not receive monensin had greater haptoglobin concentrations on day 3 postpartum than cows receiving monensin. The decrease in serum haptoglobin concentration for cattle receiving monensin may be partly related to the effect of monensin on changing rumen microflora. Monensin is known to increase the microbial population that produces propionate, improving energy metabolism $[43,44]$. The increase in glucose production may lead to fewer subclinical metabolic disorders such as hyperketonemia and fatty liver syndrome by decreasing negative energy balance during the transition period [44].

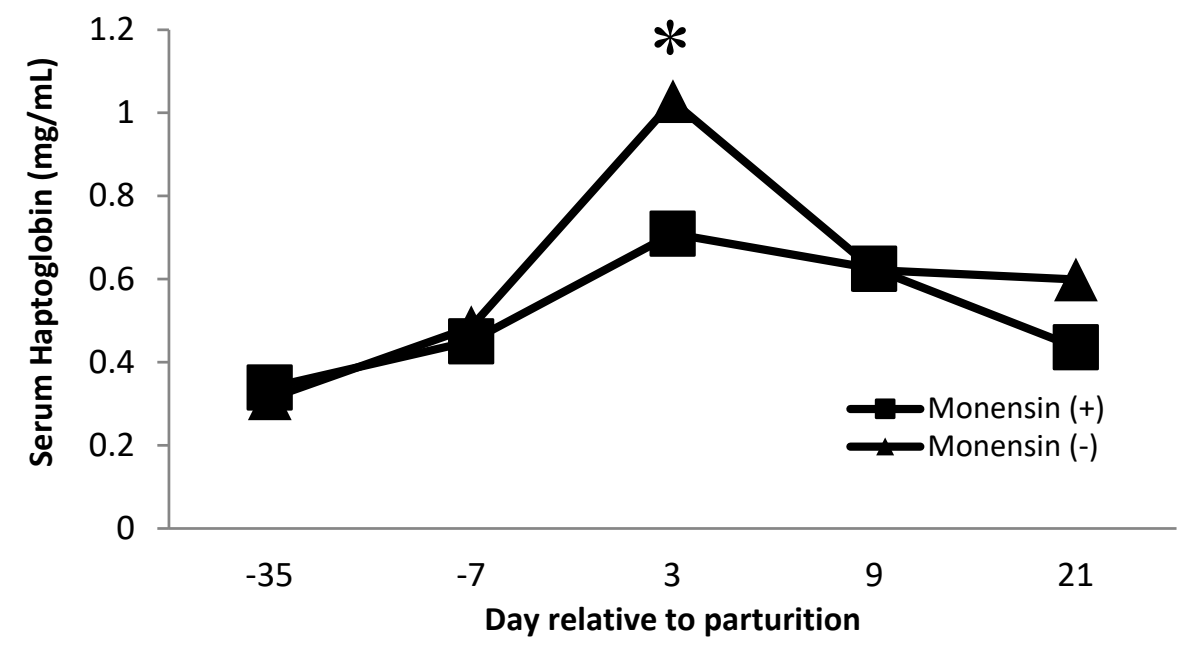

Figure 3. Serum haptoglobin concentration for multiparous Holstein dairy cows $(n=80$, total) that were fed diets with crude protein levels $(10.3 \%, n=40$ vs. $12.2 \%$ dry matter basis, $n=40)$, and within each crude protein group fed monensin (400 mg/day per head or none) and vitamin A (110 IU $/ \mathrm{kg}$ body weight or none) during prepartum period (from day -35 to the day of calving). All cows received a common lactation ration postpartum. Dietary monensin $\times$ time interaction $(p=0.01)$. Asterisks show significant differences at time point specified.

Furthermore, haptoglobin concentration is related to protein levels. Cows receiving low crude protein had greater $(p=0.01$, Table 5$)$ haptoglobin concentration than cows receiving high crude protein. There is no previous evidence in the literature about protein levels in the diet modifying haptoglobin concentration; therefore, further evidence is needed. It is important to recognize that haptoglobin is an acute-phase protein that is 
elevated during inflammation. Haptoglobin was measured to evaluate the effect of specific dietary factors that might improve the immune status of the animal. Therefore, a decrease in haptoglobin would be an indication of a lower immune system stimulation. In that regard, monensin and higher $\mathrm{CP}$ diets might lead to a better plane of nutrition that improves overall immune status.

Table 5. Serum metabolites for multiparous Holstein dairy cows $(n=80$, total) that were fed diets with crude protein levels $(10.3 \%, n=40$ vs. $12.2 \%$ dry matter basis, $n=40)$, and within each crude protein group fed monensin ( $400 \mathrm{mg} / \mathrm{day}$ per head or none) and vitamin A (110 IU/ kg body weight or none) during prepartum period (from day -35 to the day of calving). All cows received a common lactation ration postpartum.

\begin{tabular}{|c|c|c|c|c|c|c|c|c|c|c|c|c|c|}
\hline & \multicolumn{6}{|c|}{ Main Effect } & \multirow{3}{*}{ SEM $^{1}$} & \multirow{2}{*}{\multicolumn{6}{|c|}{$p$-Value }} \\
\hline & \multicolumn{2}{|c|}{ Vitamin A } & \multicolumn{2}{|c|}{ Protein } & \multicolumn{2}{|c|}{ Monensin } & & & & & & & \\
\hline & $(+)$ & $(-)$ & High & Low & $(+)$ & $(-)$ & & Pro & Mon & Vit. A & $\begin{array}{l}\text { Pro } \times \\
\text { Vit. A }\end{array}$ & $\begin{array}{c}\text { Mon } \\
\times \text { Vit. } \\
\quad \text { A }\end{array}$ & $\begin{array}{r}\text { Pro } \times \\
\text { Mon }\end{array}$ \\
\hline $\mathrm{Hpt}^{2}$ & 0.57 & 0.54 & 0.5 & 0.61 & 0.54 & 0.57 & 0.03 & 0.01 & 0.54 & 0.44 & 0.76 & 0.77 & 0.13 \\
\hline TBARS $^{3}$ & 2.22 & 2.01 & 2.15 & 2.08 & 2.07 & 2.16 & 0.08 & 0.53 & 0.43 & 0.06 & 0.77 & 0.24 & 0.14 \\
\hline $\mathrm{RBP}^{4}$ & 4.16 & 4.08 & 4.11 & 4.13 & 4.21 & 4.02 & 0.21 & 0.97 & 0.53 & 0.80 & 0.92 & 0.70 & 0.04 \\
\hline
\end{tabular}

${ }^{1}$ Largest SEM reported; ${ }^{2}$ expressed in $\mathrm{mg} / \mathrm{mL} ;{ }^{3}$ expressed in $\mu \mathrm{M} ;{ }^{4}$ expressed in $\mu \mathrm{g} / \mathrm{mL} ; \mathrm{Hpt}=$ haptoglobin; TBARS = thiobarbituric acid reactive species; $\mathrm{RBP}=$ retinol-binding protein; Pro = dietary crude protein; Mon = monensin; Vit. A = dietary vitamin $\mathrm{A} ;$ Pro $\times$ Vit. $=$ dietary crude protein and vitamin A interaction; Mon $\times$ Vit. = monensin and dietary vitamin A interaction; Pro $\times$ Mon $=$ dietary crude protein and monensin interaction.

Lipid oxidation measured by TBARS assay determines the concentration of malondialdehyde (MDA) in the serum. Vitamin A supplementation affected serum MDA concentration $(p=0.06)$. The result indicates that cows receiving vitamin $\mathrm{A}$ tended to have a greater serum MDA than cows that did not. Although vitamin A and the $\beta$-carotene (precursor of vitamin A) have been shown to have antioxidant capacities [45], in the current study, vitamin A supplementation increased TBARS, an indicator of lipid oxidation. For instance, Dal-Pizzol et al. [46] reported an increase in lipid oxidation assessed through tests such as TBARS, superoxide dismutase, and others in rat Sertoli cells and concluded that retinol supplementation might cause this oxidation. Another study in the literature has shown similar results with retinol supplementation, concluding that retinol led to an increased TBARS and intracellular reactive species formation [47]. The current study provides evidence that vitamin A supplementation may have a deleterious effect on cellular oxidation; however, further investigation is required because serum MDA was the only measure used to determine the antioxidant capacity of cows in our experiment.

Serum retinol-binding protein showed a protein $\times$ monensin interaction $(p=0.04$, Figure 4), where cows fed with the combination of high $\mathrm{CP}$ and monensin showed a greater RBP concentration than cows fed with high CP and no monensin (4.52 vs. $3.71 \mu \mathrm{g} / \mathrm{mL})$. This interaction might be related to combining a better amino acid availability (from the high $\mathrm{CP}$ ) and energy metabolism (from monensin inclusion). Lindberg et al. [16] showed that a greater dietary protein increased hepatic transport proteins, such as RBP, indicating a positive impact on the synthesis and release. In the current study, serum RBP concentration was not significantly affected by dietary crude protein alone $(p>0.98)$. This difference between the results observed in the present study and the Lindberg et al. study might be attributed to the higher crude protein concentration in prepartum diets used by Lindberg et al. We [48] also did not observe a difference in serum RBP of rats fed different levels of dietary crude proteins supplemented with or without vitamin A. 


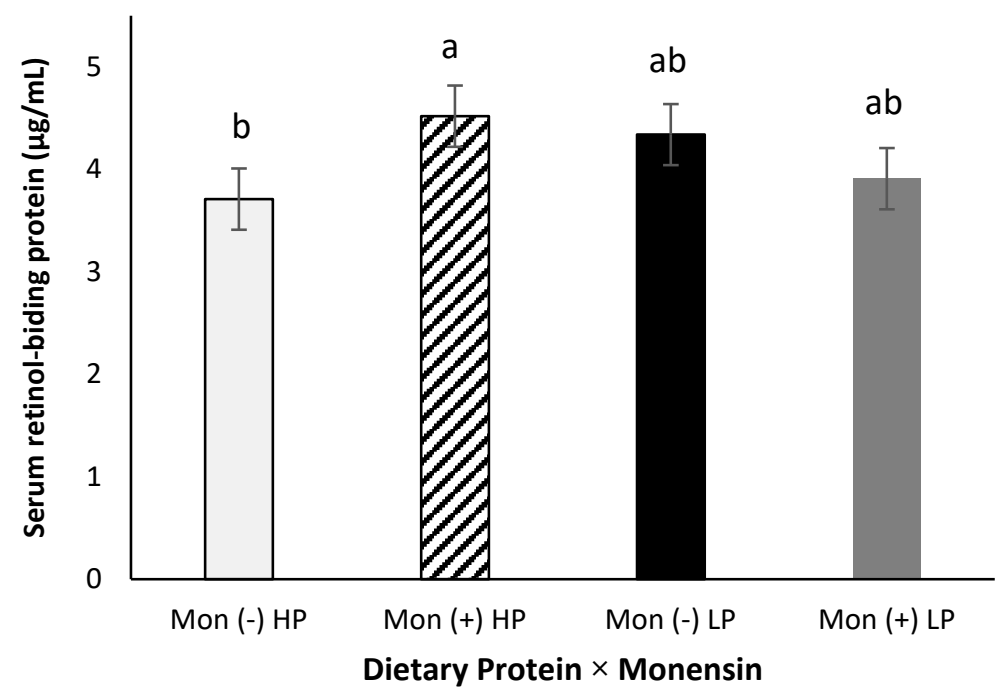

Figure 4. Serum retinol-binding protein (RBP) concentration for multiparous Holstein dairy cows ( $n=80$, total) that were fed diets with crude protein levels $(10.3 \%, n=40$ vs. $12.2 \%$ dry matter basis, $n=40)$, and within each crude protein group fed monensin (400 mg/day per head or none) and vitamin A (110 IU $/ \mathrm{kg}$ body weight or none) during prepartum period (from day -35 to the day of calving). All cows received a common lactation ration postpartum. Dietary protein $\times$ monensin $(p<0.04)$. Different letters mean statistical difference between the treatments.

Serum RBP concentrations were much lower than reported in the literature [49]. Abd Eldaim (2010) [49] reported an average concentration in early postpartum lactating dairy cows of $45 \mu \mathrm{g} / \mathrm{mL}$ using a Western blot analysis. The significantly lower RBP concentrations observed in the current study might be explained by the different methods used to determine RBP concentrations. Furthermore, Lindberg (1999) [16] also reported significantly greater serum RBP concentrations in periparturient multiparous and primiparous cows using a monoclonal antibody ELISA developed in their lab. The polyclonal antibody ELISA used in our determination of serum RBP may not be as sensitive as needed. Limited commercially available RBP ELISA are currently being produced, and further product development with greater sensitivity and specificity is required. Despite the lower serum RBP concentrations, a similar pattern in serum RBP concentrations is observed (data not shown) compared to the literature [16,49], with a reduced concentration close to the parturition. This reduction might be related to the RBP moving from serum into colostrum following other proteins passed from dam to offspring [49].

\subsection{Serum Vitamins and Retinoid Concentrations}

No significant difference was detected among diets on serum retinol concentrations $(p>0.27$, Table 6). Lindberg et al. [16] observed that primiparous dairy cows supplemented with high crude protein in prepartum had a greater serum retinol concentration. In the current study, however, only multiparous cows were included. Furthermore, there was no significant difference in the interactions tested for serum retinol concentrations $(p>0.12)$. Our data follow the trend reported in the literature $[17,30,50]$ in that serum retinol concentration decreased during the prepartum period (data not shown). Hydrolyzed retinyl-esters (RE) and carotenoids are taken up by the liver and stored in parenchymal cells and liver adipose cells. Stored RE is mobilized as retinol by a specific circulating protein called retinol-binding protein (RBP). Retinol-binding protein is responsible for the transportation of retinol to extrahepatic tissue throughout the body [51]. Retinol is initially absorbed by the lymphatic system, and excess is stored in the liver, and this may explain why an increase in retinol was not observed in serum during or immediately after supplementation. On the other hand, Pulvogel et al. [31] observed that cows supplemented with vitamin A (500,000 IU / day) during the dry period showed a greater concentration of retinol in the 
plasma at the end of the dry period and between $\mathrm{d} 1$ and $\mathrm{d} 5$ after calving compared with the animals in the control group.

Table 6. Serum concentration for various retinoids, $\alpha$-Tocopherol, and $\beta$-carotene of multiparous Holstein dairy cows ( $n=80$, total) that were fed diets with crude protein levels $(10.3 \%, n=40 \mathrm{vs.} 12.2 \%$ dry matter basis, $n=40)$, and within each crude protein group fed monensin (400 $\mathrm{mg} /$ day per head or none) and vitamin A (110 IU/ kg body weight or none) during prepartum period (from day -35 to the day of calving). All cows received a common lactation ration postpartum.

\begin{tabular}{|c|c|c|c|c|c|c|c|c|c|c|c|c|c|}
\hline \multirow[b]{3}{*}{ Items } & \multicolumn{6}{|c|}{ Main Effect } & \multirow{3}{*}{ SEM $^{1}$} & \multirow{2}{*}{\multicolumn{6}{|c|}{$p$-Value }} \\
\hline & \multicolumn{2}{|c|}{ Vitamin A } & \multicolumn{2}{|c|}{ Protein } & \multicolumn{2}{|c|}{ Monensin } & & & & & & & \\
\hline & $(+)$ & $(-)$ & High & Low & $(+)$ & $(-)$ & & Pro & Mon & Vit. A & $\begin{array}{l}\text { Pro } \times \\
\text { Vit. A }\end{array}$ & $\begin{array}{c}\text { Mon } \\
\times \text { Vit. } \\
\quad \text { A }\end{array}$ & $\begin{array}{r}\text { Pro } \times \\
\text { Mon }\end{array}$ \\
\hline $\begin{array}{l}\text { Retinol } \\
(\mu \mathrm{g} / \mathrm{mL})\end{array}$ & 2.10 & 1.92 & 2.03 & 2.00 & 1.96 & 2.06 & 0.12 & 0.82 & 0.52 & 0.27 & 0.12 & 0.69 & 0.94 \\
\hline $\begin{array}{l}\text { 13-cis RA } \\
(\mathrm{ng} / \mathrm{mL})\end{array}$ & 9.42 & 7 & 7.9 & 8.5 & 8.6 & 7.8 & 0.41 & 0.24 & 0.19 & $<0.01$ & 0.02 & 0.36 & 0.06 \\
\hline $\begin{array}{l}\text { All-trans RA } \\
(\mathrm{ng} / \mathrm{mL})\end{array}$ & 7.3 & 7.2 & 7.2 & 7.3 & 7.3 & 7.2 & 0.28 & 0.83 & 0.76 & 0.78 & 0.38 & 0.98 & 0.86 \\
\hline $\begin{array}{l}\alpha \text {-Tocopherol } \\
(\mu \mathrm{g} / \mathrm{mL})\end{array}$ & 2.92 & 3.21 & 3.03 & 3.09 & 2.91 & 3.22 & 0.2 & 0.83 & 0.29 & 0.32 & 0.89 & 0.62 & 0.63 \\
\hline $\begin{array}{l}\beta \text {-carotene } \\
(\mu \mathrm{g} / \mathrm{mL})\end{array}$ & 12.9 & 12.3 & 13.3 & 11.9 & 12.6 & 12.7 & 1.66 & 0.75 & 0.82 & 0.60 & 0.56 & 0.78 & 0.09 \\
\hline
\end{tabular}

Similar to serum retinol concentration, no significant treatment effect was detected over time for either $\alpha$-tocopherol or $\beta$-carotene $(p=0.96$ and 0.98 , respectively; data not shown). As reported by previous studies [17,50,52], both serum $\alpha$-tocopherol and $\beta$ carotene decreased around the time close to the parturition and recovered postpartum. The dramatic decrease in serum vitamin concentration occurs likely because of the large requirements needed for colostrogenesis. This occurs via diet supplies, and stored lipidsoluble vitamins, such as vitamin A, are shunted toward the mammary gland [49].

Dietary factors contributed to changes in serum concentrations of 13-cis and all-trans retinoic acid. There was a vitamin $\mathrm{A} \times$ protein interaction on 13-cis retinoic acid $(p=0.02)$, where cows receiving vitamin $\mathrm{A}$ and low crude protein showed a greater concentration. Furthermore, on day 3 and day 9 postpartum, cows receiving vitamin A supplementation had greater $(p<0.01)$ concentrations of 13-cis retinoic acid than cows that did not receive a vitamin A supplement (Figure 5). Van Merris et al. [14] demonstrated that nulliparous cows with experimentally induced Eschericia coli mastitis had significantly reduced serum concentrations of 13-cis retinoic acid. Therefore, we speculate that the increase in 13-cis retinoic acid at day 3 and day 9 for cows supplemented with vitamin A may have been related to the decrease in SCC for cows supplemented with vitamin A. However, further investigations are needed to better understand the interaction of dietary protein and vitamin A on 13-cis retinoic acid. In addition, diets did not alter serum 13-cis or all-trans retinoic acid concentrations over time ( $p=0.30$ and 0.80 , respectively, data not shown).

Cows receiving no vitamin A supplement had greater all-trans retinoic acid concentration than cows receiving the vitamin A supplement on $d-35(p<0.01$, Figure 6). Although all-trans retinoic acid might be related to increased SCC, the data from the present study do not confirm this connection because cows that did not receive vitamin A supplementation had significantly greater milk SCC (Table 1); there was no difference in all-trans retinoic over the time points analyzed, except for $\mathrm{d}-35$. Somatic cell count is used to monitor mammary gland inflammation, and interestingly, the increase in SCC seen in the current study was observed in cows not receiving vitamin A supplementation. These results provide further evidence that not only does vitamin A play a role in immune function, 
but supplementation of vitamin A also improves mammary immune status. There were tendencies for protein $\times$ monensin interaction on 13-cis retinol acid and $\beta$-carotene serum concentration ( $p=0.06 ; 0.09$, respectively), where cows fed with low protein diets associated with monensin inclusion had a greater 13-cis retinol acid than animals fed with low protein without monensin or high protein with monensin. Moreover, cows fed with low protein diets with monensin had a greater $\beta$-carotene than cows fed with low protein without monensin. There is no evidence of similar effects in the literature; therefore, further investigations can help to better understand the interaction of these metabolites as both have important functions in immunity.

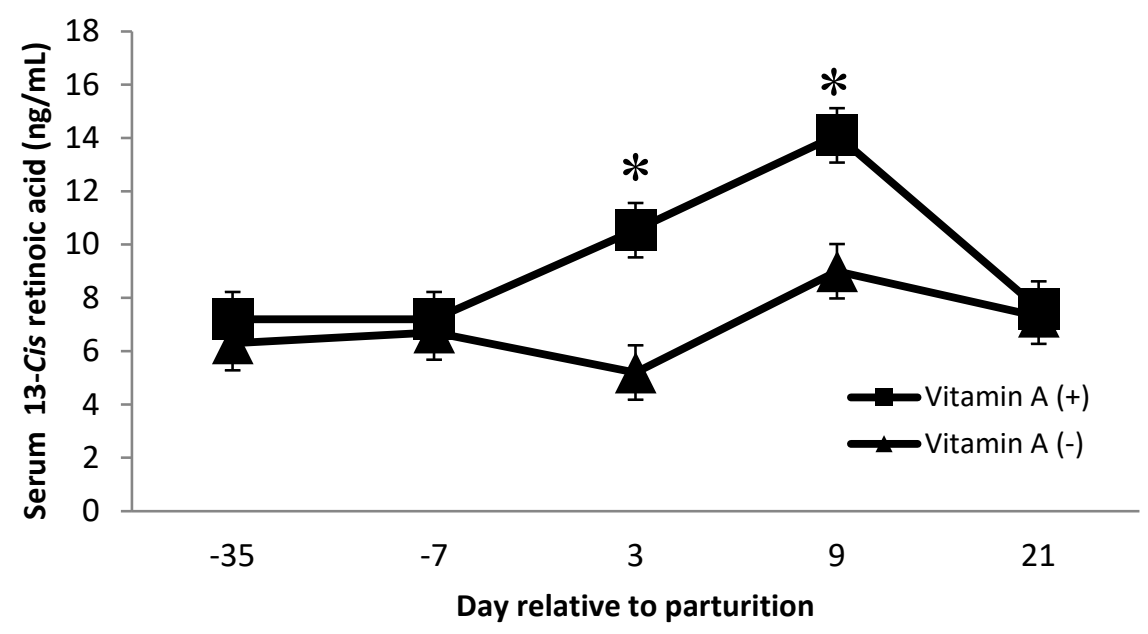

Figure 5. Serum 13-Cis retinoic acid concentrations $(\mathrm{ng} / \mathrm{mL})$ for multiparous Holstein dairy cows ( $n=80$, total) that were fed diets with crude protein levels $(10.3 \%, n=40$ vs. $12.2 \%$ dry matter basis, $n=40)$, and within each crude protein group fed monensin (400 mg/day per head or none) and vitamin A (110 IU / kg body weight or none) during prepartum period (from day -35 to the day of calving). All cows received a common lactation ration postpartum. Dietary vitamin $\mathrm{A} \times$ time interaction $(p<0.01)$. Asterisks show significant differences at time point specified.

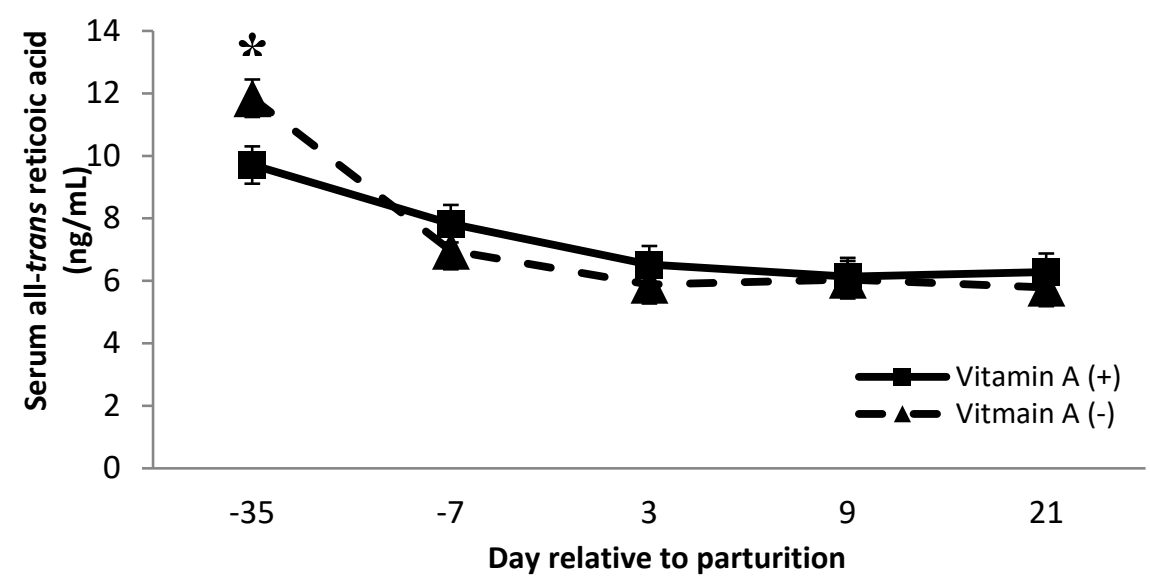

Figure 6. Serum all-trans retinoic acid concentration $(\mathrm{ng} / \mathrm{mL})$ for multiparous Holstein dairy cows ( $n=80$, total) that were fed diets with crude protein levels $(10.3 \%, n=40$ vs. $12.2 \%$ dry matter basis, $n=40)$, and within each crude protein group fed monensin (400 $\mathrm{mg} /$ day per head or none) and vitamin A (110 IU $/ \mathrm{kg}$ body weight or none) during prepartum period (from day -35 to the day of calving). All cows received a common lactation ration postpartum. Dietary vitamin $\mathrm{A} \times$ time interaction $(p=0.005)(p<0.01)$. Asterisks show significant differences at time point specified. 


\subsection{Gene Expression Analyses}

An effect of high crude protein on PBMC expression of TNF- $\alpha$ was observed in the present study, where cows receiving high crude protein had greater $(p=0.04$, Figure 7$)$ TNF- $\alpha$ gene expression. The interaction of protein by vitamin A on gene expression of ICAM in PBMC is shown in Figure 7, where cows receiving high crude protein and vitamin A supplement had a greater $(p=0.05$, Table 7$)$ expression of ICAM than the cows receiving vitamin $A$ and low crude protein, requiring further investigations. Intracellular adhesion molecule (ICAM) expression is mediated by the expression and binding of both TNF- $\alpha$ and 9-cis retinoic acid, as demonstrated by Chadwick et al. [53] in immortalized human aortic endothelial cells. As both TNF- $\alpha$ and 9-cis retinoic acid were affected synergistically to aid in the expression of ICAM, it may explain why cows receiving vitamin A had greater expression of ICAM in isolated PBMCs.
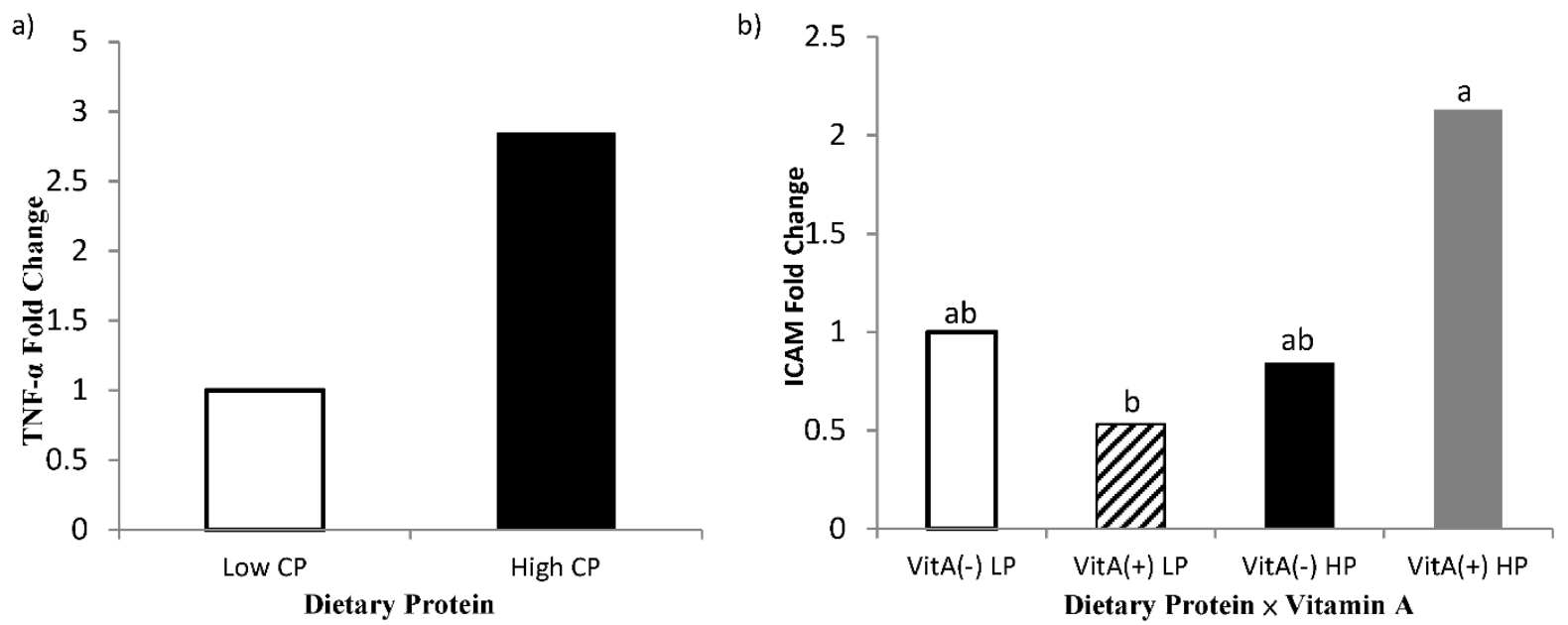

Figure 7. Fold change of PBMC gene expression of tumor necrosis factor- $\alpha$ (TNF- $\alpha$; Panel a) and intercellular adhesion molecule-1 (ICAM; Panel b) for multiparous Holstein dairy cows ( $n=80$, total) that were fed diets with crude protein levels $(10.3 \%, n=40$ vs. $12.2 \%$ dry matter basis, $n=40)$, and within each crude protein group fed monensin (400 mg/day per head or none) and vitamin A (110 IU / kg body weight or none) during prepartum period (from day -35 to the day of calving). All cows received a common lactation ration postpartum. Dietary crude protein effect and dietary protein $\times$ vitamin A interaction ( $p=0.04,0.05$, respectively).

Table 7. PBMC gene expression (delta Ct) of interleukin 1 beta (IL1 $\beta$ ), interleukin 6 (IL6), tumor necrosis factor alpha (TNF- $\alpha)$, and intercellular adhesion molecule 1 (ICAM) for multiparous Holstein dairy cows $(n=80$, total) that were fed diets with crude protein levels $(10.3 \%, n=40$ vs. $12.2 \%$ dry matter basis, $n=40)$, and within each crude protein group fed monensin (400 mg/day per head or none) and vitamin A (110 IU/ kg body weight or none) during prepartum period (from day -35 to the day of calving). All cows received a common lactation ration postpartum.

\begin{tabular}{|c|c|c|c|c|c|c|c|c|c|c|c|c|c|}
\hline \multirow[b]{3}{*}{ Items $^{2}$} & \multicolumn{6}{|c|}{ Main Effect } & \multirow{3}{*}{ SEM $^{1}$} & \multirow{2}{*}{\multicolumn{6}{|c|}{$p$-Value }} \\
\hline & \multicolumn{2}{|c|}{ Vitamin A } & \multicolumn{2}{|c|}{ Protein } & \multicolumn{2}{|c|}{ Monensin } & & & & & & & \\
\hline & $(+)$ & $(-)$ & High & Low & $(+)$ & $(-)$ & & Pro & Mon & Vit. A & $\begin{array}{l}\text { Pro } \times \\
\text { Vit. A }\end{array}$ & $\begin{array}{c}\text { Mon } \\
\times \text { Vit. } \\
\text { A }\end{array}$ & $\begin{array}{c}\text { Pro } \times \\
\text { Mon }\end{array}$ \\
\hline IL1 $\beta$ & 4.84 & 5.28 & 4.81 & 5.31 & 4.91 & 5.21 & 0.71 & 0.54 & 0.71 & 0.59 & 0.32 & 0.74 & 0.65 \\
\hline IL6 & 13.2 & 12.5 & 13 & 12.7 & 12.8 & 12.9 & 0.86 & 0.77 & 0.84 & 0.45 & 0.73 & 0.67 & 0.32 \\
\hline TNF- $\alpha$ & 4.62 & 5.06 & 4.09 & 5.6 & 4.34 & 5.34 & 0.62 & 0.04 & 0.17 & 0.54 & 0.07 & 0.15 & 0.23 \\
\hline ICAM & 7.42 & 7.63 & 7.09 & 7.96 & 7.22 & 7.82 & 0.49 & 0.13 & 0.29 & 0.71 & 0.05 & 0.61 & 0.34 \\
\hline
\end{tabular}

${ }^{1}$ Largest SEM reported; ${ }^{2}$ Gene expression data were analyzed using $\mathrm{Ct}$ values normalized to the average of the endogenous control genes, GAPDH and RPS9, and are presented graphically as fold change $(2-\Delta \Delta \mathrm{Ct})$ relative to the control treatment. Pro $=$ dietary crude protein Mon = monensin; Vit. A = dietary vitamin A; Pro $\times$ Vit. = dietary crude protein and vitamin A interaction; Mon $\times$ Vit. $=$ monensin and dietary vitamin A interaction; Pro $\times$ Mon $=$ dietary crude protein and monensin interaction. 
The increase in TNF- $\alpha$ for cows receiving high crude protein may also provide evidence toward the increase in ICAM expression as ICAM is induced by TNF- $\alpha$. According to the literature, ICAM is upregulated when retinoic acid is used as a treatment for cervical cancer in humans [54]. The upregulation suggests that retinol may enhance cellular emigration to sights of inflammation by upregulating the expression of ICAM in neutrophils of periparturient dairy cows. Therefore, this understanding provides evidence about why cows receiving vitamin A supplementation had lower SCC than cows not supplemented. It is important to note that greater ICAM expression resulted from the interactive effect of vitamin A supplementation and high crude protein diet. It is speculated that the greater crude protein diet may have aided immune status by improving the plane of nutrition for cows near the parturition combined with the role of vitamin A in the immune system. The better plane of nutrition may also explain the increase in TNF- $\alpha$ expression for cows receiving the higher crude protein diet. Gene expression of interleukin 1- $\beta$ and IL-6 were also measured; however, no significance was detected among dietary treatments $(p>0.45)$ or interactions $(p>0.32)$. The hepatic gene expression of TNF- $\alpha$ and RBP were also determined; however, there was no difference between the treatment $(p>0.19$; data not shown).

\section{Conclusions}

In summary, dairy cows supplemented with vitamin A during the late prepartum period showed a lower milk SCC postpartum and a greater serum TBARS concentration preand postpartum. Moreover," high crude protein diets led to a greater milk retinol content postpartum and a greater gene expression of TNF- $\alpha$ in PBMC, and low crude protein diets resulted in a greater serum haptoglobin concentration pre- and postpartum. Furthermore, the combination of high protein and monensin increased serum retinol-binding protein. Further research is required to better understand how these factors mechanistically affect the immune system and how they can be used to decrease the incidences of both mammary gland infections and metabolic disorders.

Supplementary Materials: The following are available online at https:/ /www.mdpi.com/article/10 .3390/ani11092605/s1, Supplementary file: The data presented in this study.

Author Contributions: Conceptualization, P.R. and M.A.M.; Methodology, B.C.A. and C.-Y.T.; Formal analysis, K.C.R., C.-Y.T. and C.M.S.; investigation, P.R., K.C.R., C.-Y.T. and C.M.S.; data curation, K.C.R. and P.R.; writing—original draft preparation, B.C.A.; resources, C.M. and P.R.; writing-review and editing, B.C.A., M.A.M. and P.R.; supervision, P.R.; project administration, P.R. All authors have read and agreed to the published version of the manuscript.

Funding: This study was financed in part by Elanco Animal Health, the United Dairymen of Idaho, and the University of Idaho Agriculture Experiment Station.

Institutional Review Board Statement: All the animal procedures were approved by the Institutional Animal Care and Use Committee of the University of Idaho (IACUC protocol number 2014-78).

Data Availability Statement: The data presented in this study are available in Supplementary Material.

Acknowledgments: Authors would like to acknowledge undergraduate students in the Dairy Nutrition Lab as well as Joshua Peak and staff at the UI Dairy Center. Additionally, the authors would like to acknowledge Elanco Animal Health, the United Dairymen, for the partial financial support.

Conflicts of Interest: The authors declare no conflict of interest.

\section{References}

1. Drackley, J.K. ADSA foundation scholar award: Biology of dairy cows during the transition period: The final frontier? J. Dairy Sci. 1999, 82, 2259-2273. [CrossRef]

2. Bell, A.W. Regulation of organic nutrient metabolism during transition from late pregnancy to early lactation. J. Anim. Sci. 1995, 73, 2804-2819. [CrossRef]

3. Allen, M.S.; Bradford, B.J.; Oba, M. Board-invited review: The hepatic oxidation theory of the control of feed intake and its application to ruminants. J. Anim. Sci. 2009, 87, 3317-3334. [CrossRef] [PubMed] 
4. Grummer, R.R.; Mashek, D.G.; Hayirli, A. Dry matter intake and energy balance in the transition period. Vet. Clin.-Food Anim. Pract. 2004, 20, 447-470. [CrossRef] [PubMed]

5. Caixeta, L.S.; Omontese, B.O. Monitoring and improving the metabolic health of dairy cows during the transition period. Animals 2021, 11, 352. [CrossRef] [PubMed]

6. Duffield, T.F.; LeBlanc, S.; Bagg, R.; Leslie, K.; Ten Hag, J.; Dick, P. Effect of a monensin controlled release capsule on metabolic parameters in transition dairy cows. J. Dairy Sci. 2003, 86, 1171-1176. [CrossRef]

7. Ipharraguerre, I.R.; Clark, J.H. Usefulness of ionophores for lactating dairy cows: A review. Anim. Feed Sci. Technol. 2003, 106, 39-57. [CrossRef]

8. McCarthy, M.M.; Yasui, T.; Ryan, C.M.; Pelton, S.H.; Mechor, G.D.; Overton, T.R. Metabolism of early-lactation dairy cows as affected by dietary starch and monensin supplementation. J. Dairy Sci. 2015, 98, 3351-3365. [CrossRef] [PubMed]

9. Schären, M.; Drong, C.; Kiri, K.; Riede, S.; Gardener, M.; Meyer, U.; Hummel, J.; Urich, T.; Breves, G.; Dänicke, S. Differential effects of monensin and a blend of essential oils on rumen microbiota composition of transition dairy cows. J. Dairy Sci. 2017, 100, 2765-2783. [CrossRef] [PubMed]

10. Yasui, T.; McCarthy, M.M.; Ryan, C.M.; Gilbert, R.O.; Felippe, M.J.B.; Mechor, G.D.; Overton, T.R. Effects of monensin and starch level in early lactation diets on indices of immune function in dairy cows. J. Dairy Sci. 2016, 99, 1351-1363. [CrossRef] [PubMed]

11. Sordillo, L.M. Nutritional strategies to optimize dairy cattle immunity. J. Dairy Sci. 2016, 99, 4967-4982. [CrossRef]

12. Spears, J.W.; Weiss, W.P. Role of antioxidants and trace elements in health and immunity of transition dairy cows. Vet. J. 2008, 176, 70-76. [CrossRef] [PubMed]

13. Chew, B.P. Vitamin A and $\beta$-Carotene on Host Defense. J. Dairy Sci. 1987, 70, 2732-2743. [CrossRef]

14. Van Merris, V.; Meyer, E.; Duchateau, L.; Blum, J.; Burvenich, C. All-trans retinoic acid is increased in the acute phase-related hyporetinemia during Escherichia coli mastitis. J. Dairy Sci. 2004, 87, 980-987. [CrossRef]

15. Chew, B.P. Role of carotenoids in the immune response. J. Dairy Sci. 1993, 76, 2804-2811. [CrossRef]

16. Lindberg, L.A.; Sinkkonen, H.; Pösö, A.R.; Tesfa, A.T.; Schröder, J. Production of monoclonal antibodies and enzyme immunoassay to bovine retinol-binding protein and determination of retinol-binding protein serum levels and retinol concentrations in serum and liver in dairy cows before and after parturition. Res. Vet. Sci. 1999, 66, 259-263. [CrossRef] [PubMed]

17. Chew, B.P.; Hollen, L.L.; Hillers, J.K.; Herlugson, M.L. Relationship between vitamin A and $\beta$-carotene in blood plasma and milk and mastitis in Holsteins. J. Dairy Sci. 1982, 65, 2111-2118. [CrossRef]

18. LeBlanc, S.J.; Herdt, T.H.; Seymour, W.M.; Duffield, T.F.; Leslie, K.E. Peripartum serum vitamin E, retinol, and beta-carotene in dairy cattle and their associations with disease. J. Dairy Sci. 2004, 87, 609-619. [CrossRef]

19. Purup, S.; Jensen, S.K.; Sejrsen, K. Differential effects of retinoids on proliferation of bovine mammary epithelial cells in collagen gel culture. J. Dairy Res. 2001, 68, 157-164. [CrossRef]

20. Cabezuelo, M.T.; Zaragoza, R.; Barber, T.; Viña, J.R. Role of vitamin A in mammary gland development and lactation. Nutrients 2019, 12, 80. [CrossRef]

21. Husnain, A.; Santos, J.E.P. Meta-analysis of the effects of prepartum dietary protein on performance of dairy cows. J. Dairy Sci. 2019, 102, 9791-9813. [CrossRef]

22. NRC Nutrient Requirements of Dairy Cattle. National Research Council; National Academies Press: Washington, DC, USA, 2001; ISBN 0309515211.

23. Tsai, C.Y.; Rezamand, P.; Loucks, W.I.; Scholte, C.M.; Doumit, M.E. The effect of dietary fat on fatty acid composition, gene expression and vitamin status in pre-ruminant calves. Anim. Feed Sci. Technol. 2017, 229, 32-42. [CrossRef]

24. Scholte, C.M.; Rezamand, P.; Tsai, C.Y.; Amiri, Z.M.; Ramsey, K.C.; McGuire, M.A. The effects of elevated subcutaneous fat stores on fatty acid composition and gene expression of proinflammatory markers in periparturient dairy cows. J. Dairy Sci. 2017, 100, 2104-2118. [CrossRef]

25. Heuer, C.; Schukken, Y.H.; Jonker, L.J.; Wilkinson, J.I.D.; Noordhuizen, J.P.T.M. Effect of monensin on blood ketone bodies, incidence and recurrence of disease and fertility in dairy cows. J. Dairy Sci. 2001, 84, 1085-1097. [CrossRef]

26. McDougall, S.; Young, L.; Anniss, F.M. Production and health of pasture-fed dairy cattle following oral treatment with the ionophore lasalocid. J. Dairy Sci. 2004, 87, 2967-2976. [CrossRef]

27. Duffield, T.F.; Rabiee, A.R.; Lean, I.J. A meta-analysis of the impact of monensin in lactating dairy cattle. Part 3. Health and reproduction. J. Dairy Sci. 2008, 91, 2328-2341. [CrossRef]

28. Ster, C.; Loiselle, M.C.; Lacasse, P. Effect of postcalving serum nonesterified fatty acids concentration on the functionality of bovine immune cells. J. Dairy Sci. 2012, 95, 708-717. [CrossRef]

29. Gu, B.B.; Miao, J.F.; Zhu, Y.M.; Deng, Y.E.; Zou, S.X. Protective effect of retinoid against endotoxin-induced mastitis in rats. Inflamm. Res. 2009, 58, 81-88. [CrossRef] [PubMed]

30. Oldham, E.R.; Eberhart, R.J.; Muller, L.D. Effects of supplemental vitamin A or $\beta$-carotene during the dry period and early lactation on udder health. J. Dairy Sci. 1991, 74, 3775-3781. [CrossRef]

31. Puvogel, G.; Baumrucker, C.R.; Sauerwein, H.; Rühl, R.; Ontsouka, E.; Hammon, H.M.; Blum, J.W. Effects of an enhanced vitamin A intake during the dry period on retinoids, lactoferrin, IGF system, mammary gland epithelial cell apoptosis, and subsequent lactation in dairy cows. J. Dairy Sci. 2005, 88, 1785-1800. [CrossRef]

32. Oliveira, R.C.; Guerreiro, B.M.; Morais Junior, N.N.; Araujo, R.L.; Pereira, R.A.N.; Pereira, M.N. Supplementation of prepartum dairy cows with $\beta$-carotene. J. Dairy Sci. 2015, 98, 6304-6314. [CrossRef] 
33. Fox, L.K.; Bayles, K.W.; Bohach, G.A. Staphylococcus aureus: Mastitis. In Staphylococcus aureus Infection and Disease; Springer: Boston, MA, USA; New York, NY, USA, 2001; pp. 271-294.

34. Wiedermann, A.; Tarkowski, U.; Bremell, T.; Hanson, L.Å.; Kahu, H.; Dahlgren, U.I. Vitamin A deficiency predisposes to Staphylococcus aureus infection. Infect. Immun. 1996, 64, 209-214. [CrossRef]

35. Lawson, N.D.; Berliner, N. Neutrophil maturation and the role of retinoic acid. Exp. Hematol. 1999, 27, 1355-1367. [CrossRef]

36. Johnston, L.A.; Chew, B.P. Peripartum Changes of Plasma and Milk Vitamin A and $\beta$-Carotene among Dairy Cows with or without Mastitis. J. Dairy Sci. 1984, 67, 1832-1840. [CrossRef]

37. McGrath, B.A.; Fox, P.F.; McSweeney, P.L.H.; Kelly, A.L. Composition and properties of bovine colostrum: A review. Dairy Sci. Technol. 2016, 96, 133-158. [CrossRef]

38. Huzzey, J.M.; Duffield, T.F.; LeBlanc, S.J.; Veira, D.M.; Weary, D.M.; Von Keyserlingk, M.A.G. Short communication: Haptoglobin as an early indicator of metritis. J. Dairy Sci. 2009, 92, 621-625. [CrossRef] [PubMed]

39. Galvão, K.N.; Flaminio, M.J.B.F.; Brittin, S.B.; Sper, R.; Fraga, M.; Caixeta, L.; Ricci, A.; Guard, C.L.; Butler, W.R.; Gilbert, R.O. Association between uterine disease and indicators of neutrophil and systemic energy status in lactating Holstein cows. J. Dairy Sci. 2010, 93, 2926-2937. [CrossRef] [PubMed]

40. Huzzey, J.M.; Nydam, D.V.; Grant, R.J.; Overton, T.R. Associations of prepartum plasma cortisol, haptoglobin, fecal cortisol metabolites, and nonesterified fatty acids with postpartum health status in Holstein dairy cows. J. Dairy Sci. 2011, 94, 5878-5889. [CrossRef]

41. Langlois, M.R.; Delanghe, J.R. Biological and clinical significance of haptoglobin polymorphism in humans. Clin. Chem. 1996, 42, 1589-1600. [CrossRef]

42. Trevisi, E.; Amadori, M.; Cogrossi, S.; Razzuoli, E.; Bertoni, G. Metabolic stress and inflammatory response in high-yielding, periparturient dairy cows. Res. Vet. Sci. 2012, 93, 695-704. [CrossRef]

43. Karcher, E.L.; Pickett, M.M.; Varga, G.A.; Donkin, S.S. Effect of dietary carbohydrate and monensin on expression of gluconeogenic enzymes in liver of transition dairy cows. J. Anim. Sci. 2007, 85, 690-699. [CrossRef]

44. Duffield, T.F.; Rabiee, A.R.; Lean, I.J. A meta-analysis of the impact of monensin in lactating dairy cattle. Part 1 . Metabolic effects. J. Dairy Sci. 2008, 91, 1334-1346. [CrossRef]

45. Sommer, A.; Vyas, K.S. A global clinical view on vitamin A and carotenoids. Am. J. Clin. Nutr. 2012, 96, 1204-1206. [CrossRef] [PubMed]

46. Dal-Pizzol, F.; Klamt, F.; Benfato, M.; Bernard, E.; Moreira, J.C. Retinol supplementation induces oxidative stress and modulates antioxidant enzyme activities in rat Sertoli cells. Free Radic. Res. 2001, 34, 395-404. [CrossRef] [PubMed]

47. Gelain, D.P.; de Bittencourt Pasquali, M.A.; Zanotto-Filho, A.; de Souza, L.F.; de Oliveira, R.B.; Klamt, F.; Moreira, J.C.F. Retinol increases catalase activity and protein content by a reactive species-dependent mechanism in Sertoli cells. Chem. Biol. Interact. 2008, 174, 38-43. [CrossRef] [PubMed]

48. Laarman, A.H.; Watts, J.S.; Foroudi, F.; Rezamand, P. Low dietary protein increases vitamin A absorption and deposition into milk in periparturient rats. Int. J. Vitam. Nutr. Res. 2021, 1-7. [CrossRef] [PubMed]

49. Abd Eldaim, M.A.; Kamikawa, A.; Soliman, M.M.; Ahmed, M.M.; Okamatsu-Ogura, Y.; Terao, A.; Miyamoto, T.; Kimura, K. Retinol binding protein 4 in dairy cows: Its presence in colostrum and alteration in plasma during fasting, inflammation, and the peripartum period. J. Dairy Res. 2010, 77, 27-32. [CrossRef]

50. Rezamand, P.; Hoagland, T.A.; Moyes, K.M.; Silbart, L.K.; Andrew, S.M. Energy status, lipid-soluble vitamins, and acute phase proteins in periparturient Holstein and Jersey dairy cows with or without subclinical mastitis. J. Dairy Sci. 2007, 90, 5097-5107. [CrossRef]

51. Blomhoff, R.; Blomhoff, H.K. Overview of retinoid metabolism and function. J. Neurobiol. 2006, 66, 606-630. [CrossRef]

52. Goff, J.P.; Stabel, J.R. Decreased Plasma Retinol, $\alpha$-Tocopherol, and Zinc Concentration During the Periparturient Period: Effect of Milk Fever. J. Dairy Sci. 1990, 73, 3195-3199. [CrossRef]

53. Chadwick, C.C.; Shaw, L.J.; Winneker, R.C. TNF- $\alpha$ and 9-cis-retinoic acid synergistically induce ICAM-1 expression: Evidence for interaction of retinoid receptors with NF-кB. Exp. Cell Res. 1998, 239, 423-429. [CrossRef] [PubMed]

54. Santin, A.D.; Hermonat, P.L.; Ravaggi, A.; Chiriva-Internati, M.; Pecorelli, S.; Parham, G.P. Retinoic acid up-regulates the expression of major histocompatibility complex molecules and adhesion/costimulation molecules (specifically, intercellular adhesion molecule ICAM-1) in human cervical cancer. Am. J. Obstet. Gynecol. 1998, 179, 1020-1025. [CrossRef] 